\title{
Gambaran Karakteristik Ibu, Pengetahuan, dan Praktik Pemberian Makanan Pendamping Air Susu Ibu pada Bayi di Kota Pontianak
}

\author{
Rini Andriani, ${ }^{1}$ Bambang Supriyatno, ${ }^{2}$ Damayanti R. Sjarif ${ }^{2}$ \\ ${ }^{1}$ Bagian Ilmu Kesehatan Anak Fakultas Kedokteran Universitas Tanjungpura / Rumah Sakit Kharitas Bhakti, Pontianak \\ ${ }^{2}$ Departemen Ilmu Kesehatan Anak Fakultas Kedokteran Universitas Indonesia / Rumah Sakit Cipto Mangunkusumo, Jakarta
}

Latar belakang. Stunting adalah masalah malnutrisi balita di Indonesia. Di Kalimantan Barat, prevalensinya 33,3\% berdasarkan data Riskesdas 2018. Praktik pemberian MPASI yang tidak optimal berkontribusi besar pada angka itu.

Tujuan. Sebagai langkah awal dalam pencegahan stunting dilakukan survei untuk mengetahui gambaran karakteristik ibu, pengetahuan, dan praktik pemberian MPASI pada bayi di kota Pontianak.

Metode. Studi potong lintang dilakukan pada bulan November- Desember 2018 di tiga Puskesmas Kecamatan Kota Pontianak. Pengambilan sampel dan data primer dilakukan dengan metode consecutive sampling, wawancara dan pengisian kuisioner.

Hasil. Didapatkan 110 ibu yang memenuhi kriteria inklusi dengan usia antara 26,9 \pm 5 tahun. Sebanyak 89,1\% ibu memiliki gawai dan menggunakannya untuk mencari informasi nutrisi anak (82,7\%). Ibu berpendapat informasi dari dokter (99,1\%) yang paling terpercaya. Sebanyak 4,5\% ibu memberikan MPASI dini dan 12,7\% memberikan menu tunggal pada awal pemberian MPASI. Makanan pertama yang diberikan pada bayi usia 6 bulan terutama dari golongan karbohidrat dan ditemukan keterlambatan pemberian protein hewani. Sebanyak $20 \%$ ibu berpendapat bahwa garam dan gula tidak boleh diberikan pada bayi di bawah 1 tahun. Tidak semua ibu mengetahui manfaat pemberian minyak dalam MPASI dan masih terdapat 87,3\% ibu yang berpendapat minyak tidak boleh diberikan pada usia di bawah 9 bulan. Dalam pemberian makan, terdapat ibu yang memberikan tontonan televisi/gawai saat makan (65,5\%), memarahi (14,5\%), dan memaksa anaknya untuk makan (11,8\%),

Kesimpulan. Pengetahuan ibu yang kurang mengenai praktik pemberian MPASI berbasis bukti terkini masih menjadi penyebab utama praktik MPASI yang belum optimal. Intervensi edukasi yang menyeluruh melalui media gawai diperlukan untuk mengoptimalkan praktik pemberian MPASI oleh ibu. Sari Pediatri 2021;22(5):277-84

Kata kunci: karakteristik ibu, MPASI, pengetahuan, perilaku

\section{Maternal Characteristics, Knowledge, and Practice of Complementary Feeding on Infants in Pontianak City}

Rini Andriani, Bambang Supriyatno, Damayanti R.Sjarif

Background. Stunting is a malnutrition problem of toddler in Indonesia. In West Kalimantan, the prevalence is 33.3\% based on the Riskesdas 2018. The non-optimal practice of complementary feeding made a big contribution to this figure.

Objective. As a first step in preventing stunting, a survey was conducted to describe maternal characteristics, knowledge and practices of complementary feeding to infants in Pontianak city.

Methods. A cross-sectional study was perfomed in November-December 2018 at three Public health center in Pontianak City district. Sampling and primary data were obtained by consecutive sampling, interviewing and filling out questionnaires

Result. There were 110 mothers who met the inclusion criteria with ages between $26.9 \pm 5$ years old. As many as $89,1 \%$ of mother own gawai and use it to find information about child nutrition(82,7\%). Mother thought that information from doctors $(99,1 \%)$ was the most reliable. As many as $4,5 \%$ of mothers gave complementary feeding too early and $12,7 \%$ gave a single menu at the beginning of complementary feeding. The first complementary food that given to 6 months infants was mainly from carbohydrate group. There was delayed in giving animal protein. As many as $20 \%$ of mothers stated that salt and sugar should not be given to infants under 1 year. Not all mothers know the benefits of giving oil in complementary feeding and there are $87.3 \%$ of mothers who thought oil shouldn't be given under 9 months. In terms of feeding practice, there were mother who give television show/gadget while eating $(65,5 \%)$, scolded $(14,5 \%)$, and forced their baby to eat $(11,8 \%)$. Conclusion. Lack of maternal knowledge about the practice of complementary feeding based on the current evidence is still the main cause of the suboptimal practice of complementary feeding. Comprehensive educational interventions are needed to optimize the practice of giving complementary feeding by mothers. Sari Pediatri 2021;22(5):277-84

Keywords: maternal characteristics, complementary feeding, knowledge, practice

Alamat korespondensi: Damayanti R.Sjarif. Departemen Ilmu Kesehatan Anak Fakultas Kedokteran Universitas Indonesia, Jl. Salemba Raya No. 6, Jakarta Pusat 10430. Email: ukk.npm.idai@gmail.com 
Rini Andriani dkk: Gambaran karakteristik ibu, pengetahuan, dan praktik pemberian mpasi pada bayi di kota Pontianak

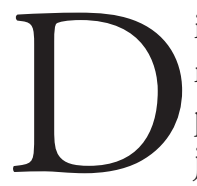
i Indonesia saat ini, permasalahan gizi meliputi permasalahan gizi ganda dengan populasi anak gizi kurang dan gizi lebih, juga terjadi defisiensi mikronutrien pada anak. ${ }^{1}$ Nutrisi yang cukup selama dua tahun pertama kehidupan berperan penting dalam kesehatan, pertumbuhan, dan perkembangan yang optimal. ${ }^{2}$ Kekurangan atau kelebihan nutrisi pada usia ini akan menimbulkan gangguan pada otak dan berpengaruh terhadap kemampuan kognitif serta perilaku anak. ${ }^{3}$

Praktik pemberian MPASI yang tidak optimal menjadi salah satu penyebab utama malnutrisi dan stunting pada bayi. Saat ini, praktik pemberian makanan pendamping ASI (MPASI) di Indonesia pada bayi usia di atas enam bulan masih belum optimal. ${ }^{4}$ Data dari World Health Organization (WHO) menunjukkan bahwa hanya $42 \%$ anak berusia $6-23$ bulan yang mendapatkan MPASI sesuai dengan rekomendasi WHO. ${ }^{5}$ Asupan nutrisi yang tidak adekuat, pemberian makanan yang kurang mengandung zat besi, variasi makanan yang kurang, cara pemberian makanan yang salah serta penyiapan makanan yang kurang higienis merupakan kesalahan-kesalahan yang sering terjadi pada praktik pemberian MPASI di Indonesia. ${ }^{4,6}$ Peningkatan pengetahuan ibu sangat penting untuk mengurangi dan mencegah kejadian malnutrisi pada bayi dan anak karena merupakan salah satu faktor yang mendasari praktik pemberian MPASI yang tepat. ${ }^{6}$

Berdasarkan Riset Kesehatan Dasar (Riskesdas) di Indonesia tahun 2018, proporsi balita dengan status gizi kurang dan buruk sebesar 13,8\% dan 3,9\% dan proporsi perawakan pendek dan sangat pendek sebesar 19,3\% dan 11,5\%. ${ }^{7}$ Berdasarkan data 2018, Provinsi Kalimantan Barat merupakan salah satu provinsi yang memiliki proporsi balita dengan status gizi kurang dan buruk yang melebihi angka nasional, yaitu sebesar $18,6 \%$ dan $5,2 \%$, begitu juga dengan proporsi balita perawakan pendek $(21,9 \%){ }^{7,8}$ Selain itu juga ditemukan 29 kasus gizi buruk di Kota Pontianak. Hal ini menjadi dasar peneliti untuk mencari gambaran karakteristik dan pengetahuan ibu mengenai MPASI di kota Pontianak dan praktik MPASI yang telah dilakukan. Data dasar ini diharapkan dapat menjadi acuan dalam menentukan pola intervensi yang tepat terhadap permasalahan yang terjadi dalam praktik pemberian MPASI pada bayi di Kota Pontianak. Pola intervensi yang ditemukan nantinya diharapkan juga dapat diimplementasikan secara nasional terhadap permasalahan dalam praktik MPASI oleh ibu.

\section{Metode}

Penelitian ini dilakukan dengan cara wawancara pada ibu disertai dengan pengisian kuesioner untuk mendapatkan gambaran karakteristik ibu, pengetahuan, dan praktik pemberian MPASI pada bayi di kota Pontianak. Populasi adalah semua ibu yang memiliki bayi berusia 6-12 bulan yang berkunjung ke Puskesmas Kecamatan kota Pontianak pada bulan November dan Desember 2018. Penelitian dilakukan di 3 Puskesmas, yaitu Puskesmas Kampung Bali, Pal 3, dan Alianyang. Sampel dipilih menggunakan metode non-probability sampling, yaitu dengan cara consecutive sampling. Sampel yang diambil berasal dari populasi terjangkau di ketiga Puskesmas tersebut yang memenuhi kriteria inklusi dan eksklusi. Kriteria inklusi adalah ibu yang memiliki minimal satu bayi berusia 6-12 bulan dan melakukan praktek pemberian MPASI kepada bayinya. Kriteria eksklusi adalah ibu yang memiliki bayi dengan kelainan bawaan, sindrom, prematur, dan berat bayi lahir rendah. Data yang diambil meliputi karakteristik ibu (usia, pendidikan terakhir, pekerjaan, dan pendapatan), kelompok usia bayi, media pencarian informasi kesehatan anak, jenis informasi kesehatan anak yang dicari, sumber infomasi kesehatan anak, pemberian ASI, pengetahuan mengenai MPASI dan praktek pemberian MPASI yang telah dilakukan oleh ibu. Penelitian ini dilakukan setelah lolos kaji etik no. 1712/UN 22.9/DL/2019.

\section{Hasil}

Pada penelitian ini didapatkan 110 subjek yang memenuhi kriteria inklusi. Kelompok umur ibu, data pendidikan ibu, pekerjaan dan penghasilan ibu beserta distribusi usia bayi saat ibu diwawancara tertera pada Tabel 1.

Pada praktik pemberian MPASI, 82 ibu (74,5\%) memberikan MPASI pertama pada saat bayi berusia 6-7 bulan. Duapuluh tiga(20,9\%) ibu memberikan MPASI pertama pada usia 5 bulan dan 5 (4,5\%) yang memberikan MPASI pertama pada usia 3-4 bulan.

Dari data penelitian menunjukkan bahwa sebagian besar ibu, yaitu $98(89,1 \%)$ ibu menggunakan gawai. Penggunaan gawai oleh ibu sebagian besar untuk mencari informasi mengenai nutrisi $(82,7 \%)$ dan penyakit (70\%) (Grafik 2.) Ibu berpendapat bahwa 
Tabel 1. Karakteristik subjek

\begin{tabular}{lcc}
\hline Karakteristik subjek & $\begin{array}{c}\text { Frekuensi } \\
(\mathrm{n}=110)\end{array}$ & $\begin{array}{c}\text { Persentase } \\
\%\end{array}$ \\
\hline Kelompok umur ibu (tahun) & & \\
19-25 & 55 & 50,0 \\
26-30 & 32 & 29,1 \\
31-41 & 23 & 20,9 \\
Pendidikan ibu & & \\
SMA & 15 & 13,6 \\
Diploma & 87 & 79,1 \\
Sarjana & 8 & 7,2 \\
Pekerjaan ibu & & \\
Bekerja & 5 & 4,5 \\
Tidak bekerja & 105 & 95,5 \\
Penghasilan ibu & & \\
Tidak ada & 105 & 95,5 \\
2,1-3,5 juta & 3 & 2,7 \\
3,5-5 juta & 2 & 1,8 \\
Ibu menggunakan gawai & & \\
Iya & 98 & 89,1 \\
Tidak & 12 & 10,9 \\
Kelompok umur bayi (bulan) & & 30,0 \\
6-7 & 33 & 35,4 \\
8-9 & 38 & \\
10-12 & 39 & \\
\hline
\end{tabular}

sumber informasi terbaik mengenai MPASI bersumber dari dokter $(99,1 \%)$ dengan media sumber informasi melalui media cetak $(93,6 \%)$ dan elektronik $(92,7 \%)$. (Grafik 1).
Data yang menunjukkan makanan yang diberikan sebagai MPASI pertama pada usia 6 bulan tertera pada Grafik 3. Pada usia 6 bulan saat memulai pemberian MPASI, ibu banyak memberikan makronutrien dari sumber karbohidrat, seperti nasi (100\%), sayur $(98,2 \%)$, dan buah $(97,3 \%)$. Sementara makronutrien dari sumber protein hewani, seperti ikan, ayam, dan telur hanya diberikan oleh sebagian ibu saat memberikan MPASI kepada bayinya di usia 6 bulan. Dalam hal variasi makanan yang diberikan, $73,6 \% \mathrm{ibu}$ sudah memberikan 2-3 macam kombinasi dalam sehari, 13,6\% bahkan memberikan lebih dari 3 kombinasi makanan dalam MPASI yang dibuat. Dalam penelitian ini ditemukan $12,7 \%$ ibu masih memberikan menu tunggal dengan kandungan makanan dari golongan karbohidrat pada awal pemberian MPASI bayi di usia 6 bulan.

Pendapat ibu mengenai pemberian garam dan gula masih bervariasi. Sebagian besar ibu setuju bahwa garam dan gula dapat diberikan kepada bayi pada usia 6 bulan. Namun, masih terdapat $22(20 \%)$ ibu yang berpendapat bahwa garam dan gula tidak boleh diberikan pada bayi (Tabel 2).

Manfaat pemberian minyak pada MPASI bayi juga baru diketahui oleh sebagian ibu, seperti minyak dapat meningkatkan kalori MPASI $(80,9 \%)$ dan dapat meningkatkan rasa MPASI bayi $(78,2 \%)$. Sebagian besar ibu justru menganggap bahwa minyak tidak boleh diberikan kepada bayi yang berusia di bawah 9 bulan $(87,3 \%)$ dan dapat meningkatkan kandungan kolesterol makanan bayi.

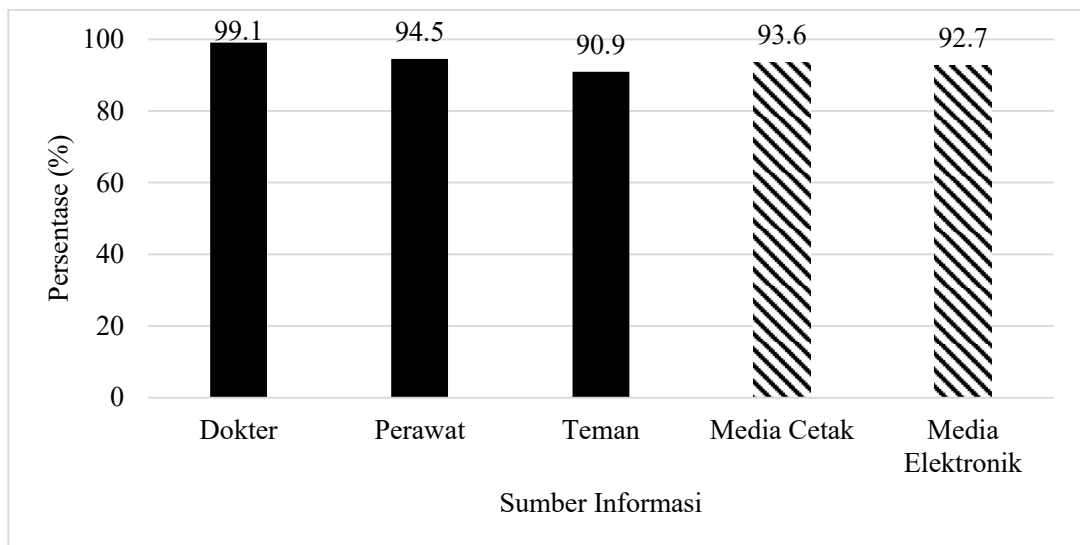

Grafik 1. Sumber informasi terbaik mengenai MPASI menurut ibu $(n=110)$ 
Rini Andriani dkk: Gambaran karakteristik ibu, pengetahuan, dan praktik pemberian mpasi pada bayi di kota Pontianak

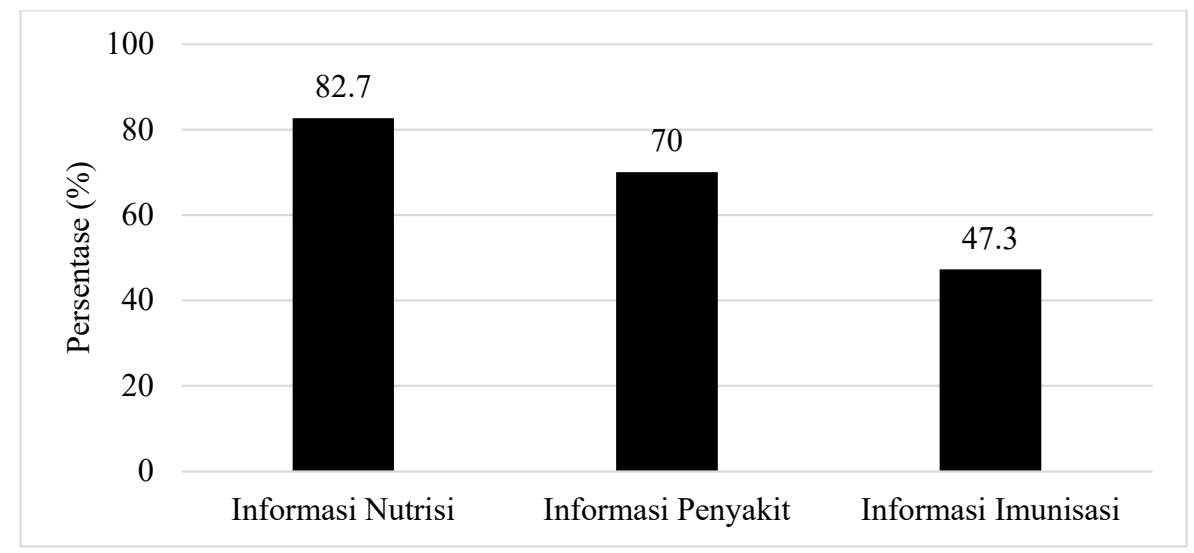

Grafik 2. Persentase tujuan penggunaan gawai oleh ibu $(n=110)$

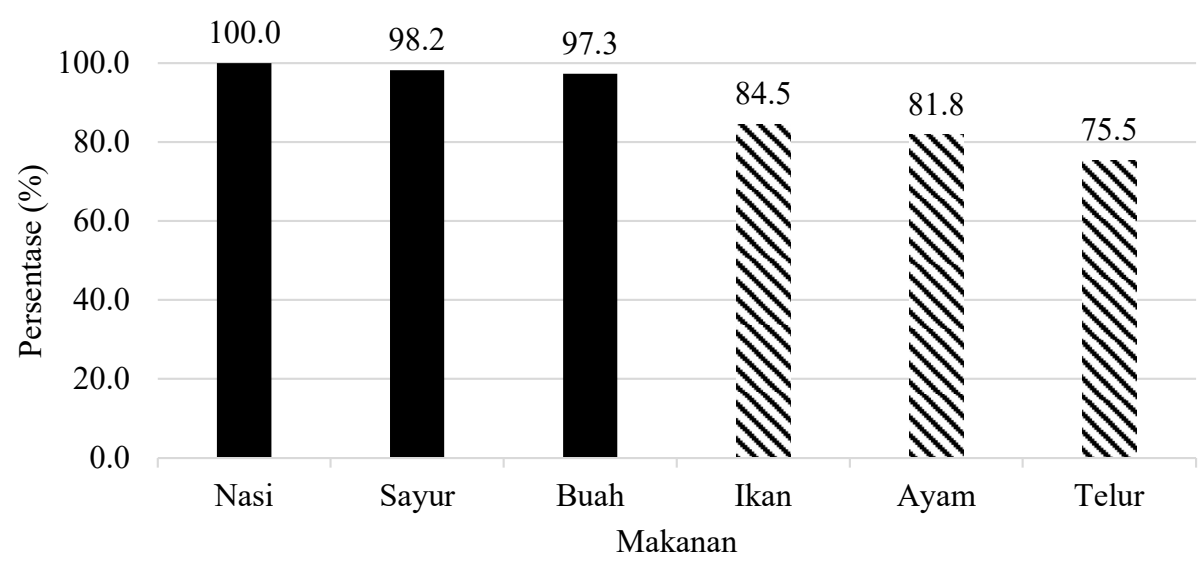

Grafik 3. Makanan yang diberikan ibu pada usia 6 bulan

Tabel 2. Persentase ibu tentang garam dan gula dalam makanan bayi $(\mathrm{n}=110)$

\begin{tabular}{lllll}
\hline \multirow{2}{*}{ Pengetahuan dan pendapat ibu } & \multicolumn{3}{c}{ Tidak } \\
\cline { 2 - 5 } & $\mathrm{N}$ & $\%$ & $\mathrm{~N}$ & $\%$ \\
\hline Pendapat ibu tentang pemberian garam dan gula pada MPASI & & & & \\
Setuju garam boleh diberikan mulai usia 6 bulan & 77 & 70,0 & 33 & 30,0 \\
Setuju garam baru boleh diberikan setelah usia $\geq 1$ tahun & 33 & 30,0 & 77 & 70,0 \\
Setuju gula boleh diberikan mulai usia 6 bulan & 66 & 60,0 & 44 & 40,0 \\
Setuju gula baru boleh diberikan setelah usia $\geq 1$ tahun & 44 & 40,0 & 66 & 60,0 \\
Garam dan gula tidak boleh diberikan pada MPASI & 22 & 20,0 & 88 & 80,0 \\
\hline Pendapat ibu tentang pemberian sedikit minyak pada MPASI & & & & \\
Meningkatkan jumlah kalori MPASI & 89 & 80,9 & 21 & 19,1 \\
Dapat meningkatkan level kolesterol bayi & 87 & 79,1 & 23 & 20,9 \\
Membantu meningkatkan berat badan bayi & 80 & 72,7 & 30 & 27,3 \\
Tidak direkomendasikan untuk bayi <9 bulan & 96 & 87,3 & 14 & 12,7 \\
Membantu meningkatkan rasa MPASI & 86 & 78,2 & 24 & 21,8 \\
\hline
\end{tabular}


Rini Andriani dkk: Gambaran karakteristik ibu, pengetahuan, dan praktik pemberian mpasi pada bayi di kota Pontianak

Tabel 3. Persentase ibu tentang praktik pemberian makan pada bayi $(\mathrm{n}=110)$

\begin{tabular}{lcccc}
\hline \multirow{2}{*}{ Pengetahuan dan perilaku ibu } & \multicolumn{3}{c}{ Ya } & \multicolumn{2}{c}{ Tidak } \\
\cline { 2 - 6 } & $\mathrm{N}$ & $\%$ & $\mathrm{~N}$ & $\%$ \\
\hline Cara ibu untuk membuat anak mau makan & & & & \\
Memaksa agar bisa masuk & 13 & 11,8 & 97 & 88,2 \\
Memarahi atau menakut-nakuti & 16 & 14,5 & 94 & 85,5 \\
Memberi tontonan (televisi/gawai) & 72 & 65,5 & 38 & 34,5 \\
Mengajak anak makan sambil jalan-jalan & 84 & 76,4 & 26 & 23,6 \\
Membujuk dengan sabar & 107 & 97,3 & 3 & 2,7 \\
\hline
\end{tabular}

Dalam hal keamanan dan kebersihan MPASI yang dibuat oleh ibu, sekitar 95,5\% ibu memasak MPASI dan memanaskan saat akan diberikan kepada bayi $(92,7 \%)$. Ibu juga sudah mencuci tangan sebelum memberikan MPASI dan menggunakan sendok bersih dalam memberikan MPASI kepada bayinya.

Dalam praktik pemberian makan pada bayi, ibu melakukan beberapa cara untuk membuat bayi mau makan. Sebagian besar ibu mencoba dengan cara persuasif, tetapi masih terdapat cukup banyak ibu yang melakukan pemaksaan pada bayinya dalam proses pemberian makan (Tabel 3). Dalam hal lama waktu pemberian MPASI, terdapat 60,9\% ibu yang menyuapi bayinya dalam waktu kurang dari 30 menit, 33,6\% ibu menyuapi bayi sekitar 30-60 menit, dan 5,5\% ibu yang menyuapi hingga lebih dari 60 menit.

\section{Pembahasan}

Air susu ibu merupakan makanan yang ideal untuk bayi karena dapat memenuhi kebutuhan nutrisi bayi hingga usia 6 bulan. Oleh sebab itu, WHO merekomendasikan pemberian ASI ekslusif hingga usia 6 bulan yang kemudian dilanjutkan dengan pemberian MPASI pada usia 6 bulan sambil melanjutkan ASI hingga usia 24 bulan. ${ }^{2}$ Kami mendapatkan 80 (72,7\%) ibu yang masih memberikan ASI hingga bayi berusia 6 bulan dan 30 (27,3\%) ibu sudah berhenti ASI pada saat usia bayi di bawah 6 bulan.

Hasil penelitian kami menemukan 4,5\% ibu yang memberikan MPASI sebelum usia 4 bulan atau disebut juga sebagai MPASI dini dan 25,4\% memberikan MPASI sebelum usia 6 bulan. $^{9}$ Angka pemberian MPASI dini yang kami temukan lebih rendah dibandingkan dengan penelitian sebelumnya yang dilakukan di Palembang dan Jakarta. Data tahun 2012 di Palembang melaporkan 45,4\% bayi mendapatkan MPASI dini. ${ }^{10}$ Penelitian lain di Jakarta melaporkan 40 (12\%) bayi mendapatkan MPASI pertama di usia kurang dari 4 bulan, 95 (29,5\%) mendapatkan MPASI pertama pada usia 4-5 bulan dan $166(51,6 \%)$ bayi mendapatkan MPASI pertama pada usia 6 bulan. ${ }^{11}$ Alasan paling sering ibu memberikan MPASI dini adalah anak sering menangis dan rewel (40\%) serta ASI yang tidak cukup (25,9\%). ${ }^{11}$

Bayi yang mendapat MPASI dini sebelum usia 4 bulan memiliki risiko terjadinya gagal tumbuh sebesar 4,5 kali. ${ }^{12}$ Pada bayi yang mendapatkan ASI ekslusif dan MPASI dini dibandingkan dengan bayi yang mendapat MPASI pada usia 4-6 bulan ditemukan ukuran lingkar pinggang, massa lemak punggung, indeks massa tubuh, dan presentase lemak seluruh tubuh yang lebih tinggi pada masa kanak-kanak dan remaja awal. ${ }^{13}$

Pemberian MPASI pada bayi dipengaruhi oleh beberapa faktor, seperti pengalaman ibu, kebiasaan keluarga, budaya, serta keadaan sosial ekonomi. ${ }^{14}$ Pada penelitian kami, 99,1\% ibu berpendapat bahwa sumber terbaik untuk mendapatkan informasi mengenai MPASI berturut-turut adalah dari dokter, melalui media cetak, dan media elektronik. Sembilanpuluh delapan $(89,1 \%)$ ibu menggunakan gawai untuk mencari informasi kesehatan, terutama mengenai nutrisi dan penyakit anak. Penelitian yang dilakukan oleh Sulistyowati ${ }^{11}$ pada tahun 2013 melaporkan bahwa 30\% ibu mendapatkan informasi dari petugas kesehatan, 22\% berasal dari kader Posyandu, 18,6\% dari keluarga, dan $17,1 \%$ dari media elektronik. Penelitian lain yang dilakukan di Inggris melaporkan bahwa $34 \%$ ibu mendapatkan informasi mengenai MPASI dari keluarga dan teman, $28 \%$ dari grup media sosial, $22 \%$ dari internet, dan sisanya dari forum-forum diskusi daring, seperti facebook dan netmums yang 
Rini Andriani dkk: Gambaran karakteristik ibu, pengetahuan, dan praktik pemberian mpasi pada bayi di kota Pontianak

bertema mengenai tipe makanan yang akan diberikan $(89 \%)$ dan dihindari $(75 \%)$ serta informasi nutrisi $(47 \%){ }^{15}$

Kami menemukan bahwa sumber makronutrien utama yang diberikan oleh ibu sebagai MPASI pertama saat bayi berusia 6 bulan adalah dari golongan karbohidrat. Tidak semua ibu memberikan protein hewani saat awal pemberian MPASI kepada bayi di usia 6 bulan. Pemberian makronutrien dari sumber protein hewani masih kurang dibandingkan dengan sumber yang berasal dari karbohidrat. Hal ini sejalan dengan penelitian sebelumnya yang juga melaporkan bahwa di Indonesia, MPASI yang umum diberikan pertama kali pada bayi adalah pisang dan tepung beras yang dicampur dengan ASI. Dalam hal ini, pisang dan tepung beras juga merupakan makronutrien yang bersumber dari karbohidrat. ${ }^{16}$ Penelitian yang dilakukan di Jakarta melaporkan bahwa 76,3\% ibu memberikan bubur susu saat pertama kali memberikan MPASI pada anak. ${ }^{11}$ Di Indonesia, pada kelompok usia $0,5-1,9$ tahun, $32 \%$ bayi laki-laki dan $35 \%$ perempuan di perkotaan serta $45 \%$ bayi laki-laki dan $52 \%$ perempuan di perdesaan mendapatkan asupan protein di bawah Angka Kecukupan Gizi (AKG) Indonesia. ${ }^{17}$ Sementara dari WHO menyarankan pemberian MPASI pada bayi di usia 6 bulan harus dalam komposisi yang seimbang antara makronutrien dari sumber karbohidrat, protein hewani, dan lemak/ minyak. Protein hewani disarankan berjumlah sekitar 10-15\%, karbohidrat 45-50\%, dan lemak berkisar $30-45 \%$ dari total kalori yang dibutuhkan oleh bayi agar bayi dapat mencapai pertumbuhan yang optimal di usianya. Sumber utama protein lokal yang dapat ditemukan di Indonesia adalah ikan, daging, unggas, dan telur. Sumber makanan ini dapat dipilih sebagai MPASI bayi untuk mengisi celah dari kekurangan nutrisi ini. ${ }^{18,19}$

Kami menemukan $12,7 \%$ ibu yang memberikan MPASI pada bayi dengan menu tunggal. Menu tunggal adalah MPASI yang dibuat dari 1 jenis makanan. Pemberian menu tunggal banyak menggunakan bahan makanan yang bersumber dari makronutrien karbohidrat, seperti nasi, sayur, dan buah. Hal yang sama juga terjadi saat ibu memberikan kombinasi makanan dalam menu MPASI yang dibuat.

Kombinasi 2-3 macam menu dalam sehari telah diberikan oleh 73,6\% ibu, 13,6\% bahkan memberikan lebih dari 3 kombinasi makanan dalam MPASI yang dibuat, tetapi kombinasi yang dibuat banyak berasal dari sumber makronutrien karbohidrat.

Sebagai contoh, menu bubur nasi memakai kentang, wortel, dan brokoli dengan kuah kaldu ayam tanpa memakai daging ayam. Menu tersebut belum sesuai dengan rekomendasi dari WHO dalam hal nutrisi yang cukup untuk bayi, baik dari segi jumlah kalori maupun jenis makronutrien yang diberikan. Rekomendasi WHO tentang keaneka-ragaman pangan minimum atau minimum dietary diversity (MDD) pada bayi berusia 6-23 bulan, yaitu mengonsumsi empat atau lebih dari tujuh kelompok makanan (karbohidrat, kacang-kacangan, produk susu, daging, telur, buah dan sayuran yang kaya akan Vitamin A, serta buah dan sayuran lainnya) dalam sehari memenuhi kebutuhan energi dan gizi. ${ }^{20}$

Kami juga menemukan bahwa tidak semua ibu mengetahui manfaat penambahan minyak dalam MPASI bayi. Sebagian ibu malah berpendapat bahwa minyak memberikan efek negatif bagi bayi, seperti meningkatkan kolesterol dan minyak tidak boleh diberikan untuk bayi yang berusia di bawah 9 bulan. Penemuan ini bertolakbelakang dengan rekomendasi yang diberikan oleh WHO dan Ikatan Dokter Anak Indonesia (IDAI) bahwa lemak harus ditambahkan secara rutin ke dalam MPASI bayi dari sejak usia 6 bulan. Lemak yang terkandung di dalam minyak memiliki peran yang penting. Lemak akan meningkatkan kepadatan energi makanan dan membuat MPASI terasa lebih enak. Penambahan lemak membuat kandungan kalori MPASI lebih tinggisehingga dapat dengan mudah mencukupi kebutuhan energi harian bayi. Lemak juga membantu penyerapan vitamin A dan vitamin yang larut dalam lemak lainnya. Minyak juga menyediakan asam lemak esensial. Lemak harus terdiri dari 30-45\% dari total energi yang disediakan oleh ASI dan makanan pendamping secara bersamaan. ${ }^{21}$

Dalam perilaku pemberian garam pada MPASI, terdapat $77(70 \%)$ ibu berpendapat bahwa garam boleh diberikan mulai usia 6 bulan dan $33(30 \%)$ ibu berpendapat bahwa garam baru boleh diberikan setelah usia $\geq 1$ tahun. Masih terdapat perdebatan mengenai praktik pemberian garam dalam MPASI. Kemampuan bayi dalam preferensi rasa asin sudah muncul pada usia sekitar 4 bulan dan terus berkembang hingga usia 2 tahun. ${ }^{22}$ Badan kesehatan dunia WHO tidak memberikan rekomendasi khusus untuk jumlah garam yang dapat diberikan pada anak usia di bawah 2 tahun. ${ }^{23}$ European Society For Pediatric, Gastroenterology, 
Hepatology And Nutrition (ESPGHAN) juga tidak memberikan rekomendasi khusus. Lembaga tersebut menyatakan bahwa tambahan garam tidak boleh diberikan pada makanan selama masa bayi. ${ }^{24}$ Layanan program kesehatan National Health Service merekomendasikan bahwa jumlah maksimal asupan garam untuk bayi yang berusia di bawah 12 bulan adalah $<1$ gram (setara dengan natrium $<0,4$ gram).$^{25}$ Pemberian garam pada MPASI sendiri masih menjadi perdebatan. Beberapa negara memberikan rekomendasi yang berbeda. Negara Inggris memberikan rekomendasi intake natrium pada usia 7-9 bulan sebanyak $320 \mathrm{mg} /$ hari sementara Amerika Serikat merekomendasikan $200 \mathrm{mg} / \mathrm{hari}{ }^{26}$ Rekomendasi IDAI mengizinkan penambahan garam dalam MPASI bayi dalam jumlah minimal dalam kondisi saat bayi tidak mau makan tanpa adanya tambahan rasa. ${ }^{16}$

Dalam pemberian gula pada MPASI, 67 (60,9\%) ibu berpendapat bahwa gula tambahan boleh diberikan pada anak usia 6 bulan dan 44 (40\%) ibu berpendapat bahwa gula baru boleh diberikan pada anak usia $\geq 1$ tahun. Badan kesehatan duniaWHO merekomendasikan konsumsi gula tambahan $<5 \%$ dari asupan energi total untuk anak usia di atas 2-18 tahun. ${ }^{27}$ Pada anak yang berusia $<2$ tahun, ESPGHAN merekomendasikan konsumsi gula tambahan yang lebih rendah ${ }^{28}$ Sementara American Heart Association (AHA) merekomendasikan bahwa penambahan gula pada MPASI harus dihindari pada anak usia $<2$ tahun. ${ }^{29}$ Pemberian tambahan sedikit gula dan garam dapat direkomendasikan pada MPASI buatan rumah untuk menambah rasa dan meningkatkan penerimaan bayi terhadap MPASI. ${ }^{16}$

Praktik pemberian makan pada bayi dengan metode makan responsif juga merupakan hal penting yang harus dimengerti oleh ibu dari sejak awal proses pemberian makan pada bayi. Kami menemukan beberapa cara ibu untuk membuat bayi mau makan, yaitu secara persuasif seperti membujuk $(97,3 \%)$ dan makan sambil jalan-jalan (76,4\%). Meskipun demikian, masih ditemukan adanya ibu yang melakukan pemaksaan dalam proses pemberian makan terhadap bayinya, baik dengan cara halus ataupun dengan memarahi bayinya $(14,5 \%)$ dan terdapat sekitar $65,5 \%$ ibu yang memberikan tontonan televisi/ gawai kepada bayinya saat makan.

Kami juga menemukan sekitar 39,1\% ibu memberikan makan lebih dari 30 menit. Semua hal di atas bertentangan dengan metode makan responsif yang disarankan dalam praktik pemberian MPASI yang benar. Metode makan responsif menekankan pentingnya kontak mata antara ibu dan bayi, ibu menyuapi secara langsung sambil memperhatikan tanda kenyang bayi dan mengakhiri proses pemberian makan bila bayi sudah menolak. Penting untuk dimengerti ibu bahwa tidak boleh ada target untuk jumlah makanan yang harus dihabiskan oleh bayi, tidak memaksa bayi dalam proses pemberian makan, dan tidak memberi bayi makan sambil menonton televisi ataupun alat elektronik lainnya yang bisa menghilangkan kontak antara ibu dan bayi selama proses pemberian makan tersebut. Jadwal makan harus dibuat teratur sesuai dengan tanda lapar bayi dan waktu makan diatur tidak lebih dari 30 menit. ${ }^{2,16}$

\section{Kesimpulan}

Praktik pemberian MPASI pada bayi yang dilakukan oleh ibu masih banyak yang belum sesuai dengan rekomendasi yang diberikan oleh WHO dan IDAI. Untuk itu, diperlukan intervensi edukasi secara menyeluruh melalui media gawai. Di samping itu pula, pengetahuan petugas kesehatan tentang praktik pemberian MPASI yang berbasis bukti terkini pada bayi perlu ditingkatkan.

\section{Daftar pustaka}

1. Black RE, Victora CG, Walker SP, dkk. Maternal and child undernutrition and overweight in low-income and middleincome countries. Lancet. 2013;382:427-51.

2. PAHO. Guiding principles for complementary feeding of the breastfed child. Washington DC: Pan American Health Organization, World Health Organization; 2003.

3. Waber DP, Bryce CP, Fitzmaurice GM, Zichlin M, dkk. Neuropsychological outcomes at midlife following moderate to severe malnutrition in infancy. Neuropsychology 2014;28:530.

4. Blaney S, Februhartanty J, Sukotjo S. Feeding practices among Indonesian children above six months of age: a literature review on their magnitude and quality (part 1). Asia Pacific J Clin Nutr 2015;24:16.

5. WHO, UNICEF, USAID, AED, UCDAVIS, IFPRI. Indicators for assessing infant and young child feeding practices part 3: country profiles. Geneva: World Health Organization; 2010 .

6. Blaney S, Februhartanty J, Sukotjo S. Feeding practices among Indonesian children above six months of age: a literature review on their potential determinants (part 2). Asia Pacific J Clin 
Nutr 2015;24:28

7. Kementerian Kesehatan Republik Indonesia. Hasil utama riskesdas 2018. Jakarta: Kementerian Kesehatan RI; 2018.

8. Dinas Kesehatan Kota Pontianak. Profil kesehatan kota Pontianak Tahun 2018. Pontianak: Dinas Kesehatan Kota Pontianak; 2018.

9. World Health Organization. Global strategy for infant and young child feeding. Geneva: World Health Organization; 2003.

10. Fitriana EI, Anzar J, HZ HN, Theodorus. Dampak Usia Pertama Pemberian Makanan Pendamping ASI terhadap Status Gizi Bayi Usia 8-12 Bulan di Kecamatan Seberang Ulu I Palembang. Sari Pediatri 2013;15:249-53.

11. Sulistyowati A. Pola Pemberian Makanan Pendamping ASI (MPASI) pada Bayi di Kecamatan Pasar Minggu, Jakarta Selatan [tesis]. Jakarta: Universitas Indonesia; 2013.

12. Lestari ED, Wardhani A, Murti B. Premature initiation of complementary feeding is associated with gains in weight of infants at Surakarta City, Indonesia. 24th International Congress of Pediatrics; August 15-20, 2004; Cancun, Mexico.

13. Gingras V, Aris IM, Rifas-Shiman SL, Switkowski KM, Oken E, Hivert MF. Timing of complementary feeding introduction and adiposity throughout childhood. Pediatrics 2019;144: e20191320.

14. Pak-Gorstein S, Haq A, Graham EA. Cultural influences on infant feeding practices. Pediatr Rev 2009;30:e11-21.

15. Garcia AL, Looby S, McLean-Guthrie K, Parrett A. An exploration of complementary feeding practices, information needs and sources. Int J Environ Res Public Health 2019; 16:4311.

16. UKK Nutrisi dan Penyakit Metabolik. Rekomendasi praktik pemberian makan berbasis bukti pada bayi dan batita di Indonesia untuk mencegah malnutrisi: Jakarta: Badan Penerbit IDAI; 2015

17. Sandjaja S, Budiman B, Harahap H, dkk. Food consumption and nutritional and biochemical status of 0.5-12-year-old Indonesian children: the SEANUTS study. Br J Nutr 2013;110 Suppl 3:S11-20.

18. Fahmida U, Santika O, Kolopaking R, Ferguson E. Complementary feeding recommendations based on locally available foods in Indonesia. Food Nutr Bull 2014;35(4 Suppl):S174-9.
19. Egayanti Y, Palupi NS, Prangdimurti E. Profile of complementary food consumption during the first year of life based on Indonesia Individual Food Consumption Survey 2014. Mal J Nutr 2018;24:53-61.

20. World Health Organization. UNICEF, USAID, AED, UCDAVIS, IFPRI. Indicators for assessing infant and young child feeding practices 2008 [Part I: definition]. Geneva: World Health Organization; 2008.

21. World Health Organization. Infant and young child feeding: model chapter for textbooks for medical students and allied health professionals. Geneva: World Health Organozation; 2009.

22. Beauchamp GK, Mennella JA. Flavor perception in human infants: development and functional significance. Digestion 2011;83 Suppl 1:1-6.

23. World Health Organization. Guideline: Sodium intake for adults and children. Geneva: World Health Organization; 2012.

24. Agostoni C, Decsi T, Fewtrell M, dkk. Complementary feeding: a commentary by the ESPGHAN Committee on Nutrition. J Pediatr Gastroenterol Nutr 2008;46:99-110.

25. Panel on Dietary Reference Intakes for Electrolytes and Water Standing Committee on the Scientific Evaluation of Dietary Reference Intakes. Dietery reference intakes for waters, potassium, sodium, chloride and sulfate. Washington, D.C.: National Academy Press; 2004.

26. Michaelsen KF, Weaver L, Branca F, Robertson A. Feeding and nutrition of infants and young children: guidelines for the WHO European region with emphasis on the former soviet countr. Denmark: WHO; 2003.

27. World Health Organization. Guideline: Sugars Intake for Adults and Children. Geneva: World Health Organization; 2015.

28. Fidler Mis N, Braegger C, Bronsky J, dkk. Sugar in infants, children and adolescents: a position paper of the european society for paediatric gastroenterology, hepatology and nutrition committee on nutrition. J Pediatr Gastroenterol Nutr 2017;65:681-96.

29. Vos MB, Kaar JL, Welsh JA, dkk. Added sugars and cardiovascular disease risk in children: a scientific statement from The American Heart Association. Circulation 2017;135:e1017-e34. 